\section{Race and intelligence}

\section{William J. Schull}

The Race Bomb: Skin Color, Prejudice, and Intelligence. By Paul R. Ehrlich and S. Shirley Feldman. Pp. 256. (Quadrangle/ New York Times Books: New York, 1977.) $\$ 9.95$.

The Race Bomb is still another attempt to redress the misconceptions and prejudices which surround the ostensible association of the colour of our skins with our intellectual abilities. Ehrlich and Feldman - the former a population biologist and the latter a psychologist-deplore the diversion of effort which attends the controversy over race and intelligence, but feel compelled apparently to add their ruminations to dispelling the myths and misunderstandings. In this, I wish them well but I am not sufficiently sanguine to believe much will be accomplished. Diogenes was surely not searching for an honest man, but rather one dissuaded from the comforts of prejudices by the logic of the arguments of another.

Few of the uncommitted will be influenced by this book, for it is as frequently tendentious as intellectually compelling, and panders to the commercial. The latter is a serious charge, but how else is one to interpret a title so patently intended to scare. But is the book, in fact, tendentious? I offer the following evidence: We are treated, for example, to apocryphal remarks alleged to have been made in a Salisbury (Rhodesia) hotel to one of the authors, and to a series of self-serving statements of others, admittedly biased but of such antiquity (about 1890 and 1926) that the irrelevancies which follow such as "Can you guess $x$ 's race (colour)?" hardly appeal to whatever rationality man may claim.

My disappointment with this book is not so much with the thrust of the arguments, with which I agree, nor the interpretation of the data which are cited and are generally sound, but rather the manner in which the arguments or interpretations are set out. Are statements made by Shockley or Jensen more or less trustworthy simply because they made them? If an argument is, indeed, specious or worthless, need it be so designated at the outset? Why shouldn't the intelligent reader be allowed to reach these conclusions himself or herself? Or is it because the arguments are not so persuasive? In some instances, I suspect the latter. For example, on p129, the fact that illegitimate (German) children 5 to 13 yrs old, the offspring of Black and White Ameri- can servicemen, did not differ in average intelligence is advanced as evidence of no racial differences in intelligence. The Armed Forces have had, however, and as far as I know, still have minimum standards of intellectual skills for enlistment. Thus, data of the kind cited can be used in the broader context only if the proportion of Blacks and Whites rejected are comparable. Or, the comparison of transracial adoptions with intraracial ones is clouded by the involvement of the parents - unlikely to be equal in the two instances-and a burden of historic guilt, real or imaginary, carried by many.

I think some of my disillusionment stems from the expectations which I brought to the reading of The Race Bomb. I feel betrayed; instead of the tightly reasoned series of arguments which I had anticipated, I got a sententious polemic. Can't individuals presented with "the facts" be expected to reach sensible interpretations? Or are we all so ill-deserving of trust or so unintelligent that arguments must be labelled?

The Race Bomb is not without merit, nor do I so intend to suggest. The chapter on "Intelligence and Intelligence Testing" is an especially good, albeit brief, statement of the manner in which intelligence tests are constructed, administered and scored. Types of tests are described as well as what they measure and do not measure. Issues such as the stability and constancy of the IQ are addressed, and so is the matter of when a test result may be viewed as significant, even within the properly restricted limits of the principal aim (to predict school performance) of the test. This chapter is written without cant or hyperbole. Why couldn't more of the others have followed suit? Some do, in part. Thus, for example, the chapter "Is IQ Inherited?" begins with a series of simple, but clear statements on the roles of man's nature and nurture, the utility (or otherwise) of concepts such as heritability, and various types of human biological studies which may, granted certain assumptions which are often not satisfied, provide insight into the relative importance, under a given set of circumstances, of environmental and genetic influences. But it strays to personal issues; I cite the following quotation: "Those not interested in going further [into an account of Burts' scientific peccadillos-my addition ] might wish to ruminate on the idea of a society that awards knighthood for 'science' of the calibre of Burt's". This seems to me to be about as pertinent to an analysis of why discrimination and prejudice exist as to fault the Nobel Society because it has awarded prizes for the proof of the parity principle as well as its disproof. Each of us, and the societies of which we are members, can do no better than what reason leads us to with the information at our disposal. How much can one be faulted for not doing what he or she doesn't know. One may commit a stupid act, but is it morally reprehensible, or as an earlier era might designate-sinful? I've always been lead to believe that concupiscence was essential to a sinful act. Does this mean that I condone what has occurred and about which these authors are justifiably disturbed? Not at all! But if we are or at least purport to be a rational animal, shouldn't we attempt to treat one another as such? How can one convince but not perjure?

This book will provoke many and make smug an equal or perhaps larger number. But will it persuade the "uncommitted"? I believe not; but it may urge others to form their own opinions. Read it. Some day, but apparently not soon, we may see a succinct, forceful, objective account of this controversy-an account which eschews arguments ad hominem, the same old "dramatis personae", and the seemingly irresistable urge to act out once again what has become an initiation ritual into the fellowship of liberals. When this occurs I hope Nature gives me the opportunity to review it. I don't revel in the role of curmudgeon.

William J. Schull is Director of the Center for Demographic and Population Genetics and Professor of Population Genetics at the University of Texas, Health Science Center, Houston, Texas.
The 3rd revised edition,
first in paperback, of this
standard work on human
palaeontology incor-
porates all the latest
reputable finds and
theories. Dealing with
fossil remains that hold
the key to human
evolution, environ-
mental, cultural and
especially anatomical
evidence is thoroughly
investigated.

364 pages paperback. 030429949 9. £6.50. March

\section{Cassell}

